\title{
Stem Reserve Mobilization and Sink Activity in Wheat under Drought Conditions
}

\author{
Anil K. Gupta, Kamaljit Kaur, Narinder Kaur
}

Department of Biochemistry, Punjab Agricultural University, Ludhiana, India.

Email: anilkgupta@sify.com

Received October $1^{\text {st }}, 2010$; revised November $18^{\text {th }}, 2010$; accepted November $24^{\text {th }}, 2010$.

\begin{abstract}
The effect of water deficit on stem reserve mobilization and sink activity in wheat (Triticum aestivum L.) cultivars, viz., C306 (drought tolerant) and PBW343 (drought sensitive) was studied. Drought was maintained in pot raised plants by withholding irrigation at 95 days after sowing (DAS), i.e. just five days before the initiation of anthesis. Drought induced a significant reduction in mean biomass of all the internodes of sensitive cultivar as compared to those of tolerant one. Mobilized dry matter and mobilization efficiency were observed to be higher in the internodes of tolerant cultivar, both under control and stress conditions, which resulted in enhanced translocation of stem reserves to the grains. Water soluble carbohydrates (WSC), which mainly occur as fructans, were observed to be higher in the internodes of tolerant cultivar than those of sensitive one. When drought was applied, fructans were mobilized more effectively from the internodes of tolerant cultivar. A significantly higher sucrose synthase activity in the grains of tolerant cultivar, under drought conditions, increased the sink strength by unloading the assimilates in the sink, thereby increasing further mobilization of assimilates to the grains. Grains of sensitive cultivar attained maturity much earlier as compared to the tolerant one, both under control and stress conditions. The longer duration of grain maturation in tolerant cultivar supported enhanced mobilization of stem reserves, thus restricting heavy decrease in grain yield, under stress conditions, as compared to the sensitive cultivar. It may, therefore, be concluded that certain characteristics viz., enhanced capability of fructan storage, higher mobilization efficiency, stronger sink activity and longer duration of grain maturation might help the drought tolerant cultivar in coping the stress conditions.
\end{abstract}

Keywords: Acid Invertase, Fructans, Water Soluble Carbohydrate, Sink Activity, Stem Reserve Mobilization, Sucrose Synthase, Triticum Aestivum

\section{Introduction}

In semi arid areas of the world with a Mediterranean climate, wheat crop often enters the reproductive phase when rainfall decreases and soil evaporation increases, leading to adverse water deficit conditions [1,2]. Drought limits growth and productivity of plants and plays a central role in their geographical range [3]. Wheat yields have been reported to reduce by $50-90$ per cent of their irrigated potential by drought in marginal rainfed environments, on at least 60 million hectares in the developing countries $[4,5]$. Drought is, thus, reported to be a major constraint, since it depends not only on severity and duration of the stress event, but also on the plant development stage and morphology [6].

Carbon requirements for grain filling in wheat are mainly from current assimilation by photosynthesis and remobilization of reserves from the stems [7]. Remobilization of assimilates is an active process that involves translocation of stored reserves from stems and sheaths to grains [8]. Pre-anthesis assimilate reserves in stem and sheath of wheat contribute 25 to $33 \%$ of the final grain weight [9]. Extensive studies demonstrated that water deficit conditions resulted in early senescence and more remobilization of pre-anthesis stored assimilates to grains in cereals $[10,11]$. Small grains stems stored carbohydrates in the form of glucose, fructose, sucrose and starch, but the main reserve was fructan [12]. Drought induced earlier mobilization of non-structural reserve carbohydrates (largely, fructans) from stem and leaf sheaths, which provided a greater proportion of kernel dry weight at maturity. It can account for 70-92 per cent of grain dry matter, under conditions of drought [13]. It is generally accepted that stem reserve mobilization or percentage of 
stem reserves in grains is affected by sink size, environment and cultivar [1]. It has been proposed that wheat genotypes capable of synthesizing and storing a high concentration of soluble carbohydrates in the stems prior to anthesis are more likely to exhibit improved grain yield under conditions of water deficit [14]. Variation in stem water soluble carbohydrates among wheat genotypes is one of the genetic factors that influence grain weight and yield under water limited environments [15]. The significance of drought resistant genotypes which synthesize more fructans than drought sensitive ones has been reported in literature $[16,17]$.

The mobilization of stem reserves to the grains can be studied indirectly by measuring the post anthesis changes in internodal dry matter, as in [18] and sink activity of the grains or directly by measuring the changes in internodal water soluble carbohydrate content during grain filling period, as in $[19,20]$ or a combination of all the parameters. The effect of water deficit on carbohydrate status of two wheat cultivars, viz., PBW 343 (a double dwarf cultivar sensitive to drought) and C306 (a tall cultivar tolerant to drought) during early seedling growth has already been studied [21]. With the intention to know how these two cultivars behave (in terms of fructan mobilization) during grain filling period. The aim of this investigation was to study the effect of drought (which can be successfully maintained in pot experiments) on stem reserve mobilization in these two wheat cultivars.

\section{Materials and Methods}

\subsection{Plant Materials and Growth Conditions}

Wheat (Triticum aestivum L.) cultivars, viz., PBW 343 (drought sensitive) and C306 (drought tolerant) were grown in 60 pots ( 30 for each cultivar). Each pot $(25 \mathrm{~cm}$ height and $20 \mathrm{~cm}$ diameter) was filled with $10 \mathrm{~kg}$ soil. The soil was sandy loam with $\mathrm{pH} 7.3$ to 7.4 . The pots were placed in field and sheltered from rain by a removable, transparent polythene shelter. Six seeds were sown in each pot. Plants were watered three times a week so as to maintain a soil water content close to field capacity. Drought was maintained in half of the pots by withholding irrigation at 95 days after sowing (DAS), i.e. just five days before the initiation of anthesis.

\subsection{Analysis of Biomass, Moisture Content, Mobilized Dry Matter and Mobilization Efficiency of Internodes}

The stem internodes, viz., basal, middle, apical and peduncle were oven dried at $60^{\circ} \mathrm{C}$ up to a constant weight. The moisture content of internodes was calculated by measuring the fresh and dry weight of internodes. The magnitude of mobilized dry matter of each internodes was estimated as difference between post anthesis maximum and minimum biomass. Mobilization efficiency of dry matter in each internodes was estimated by using the proportion (\%) of mobilized dry matter relative to post anthesis maximum biomass of that internode [18].

\subsection{Analysis of Moisture Content and Yield of Grains}

The percentage of moisture content was calculated by measuring the fresh and dry weight of grains. Grain yield was calculated as number of grains per spike.

\subsection{Extraction and Determination of Enzyme Activities from Grains}

Sucrose synthase (SS) \{EC 2.4.1.13\} was extracted by grinding the grains $(0.5 \mathrm{~g})$ in a cold chilled mortar with a pestle with $3 \mathrm{ml}$ of $100 \mathrm{mM}$ HEPES buffer (pH 8.2), containing $10 \mathrm{mM}$ EDTA, $15 \mathrm{mM} \mathrm{KCl}, 5 \mathrm{mM} \mathrm{MgCl}{ }_{2}$ $2 \mathrm{mM}$ sodium diethyl dithiocarbomate and $5 \mathrm{mM} \beta$-mercaptoethanol [22]. Insoluble polyvinylpolypyrrolidone (100 mg per $\mathrm{g}$ tissue) was also added while extracting the enzymes. The extract was centrifuged at $10,000 \mathrm{~g}$ for 15 min at $4^{\circ} \mathrm{C}$ and supernatants were used for enzyme estimation. The assay mixture of SS consisted of $50 \mu$ moles HEPES buffer (pH 6.5), $2 \mu$ moles UDP and $50 \mu$ moles of sucrose in a total volume of $0.4 \mathrm{ml}$. Reaction was initiated by adding $0.1 \mathrm{ml}$ of enzyme at $30^{\circ} \mathrm{C}$ and reaction was stopped by adding $0.5 \mathrm{ml}$ of alkaline copper tartrate reagent and fructose released was estimated at $510 \mathrm{~nm}$ [21].

Acid invertase (AI) $\{$ EC 3.2.1.26\} was extracted by crushing the grains $(0.5 \mathrm{~g})$ in a cold chilled mortar with a pestle with $3 \mathrm{ml}$ of $20 \mathrm{mM}$ sodium phosphate buffer $(\mathrm{pH}$ 7.0), as in [23]. The extract was centrifuged at $10,000 \mathrm{~g}$ for $15 \mathrm{~min}$ at $4^{\circ} \mathrm{C}$ and supernatants were used for enzyme estimation. AI activity was determined by incubating 160 $\mu$ moles of sodium acetate buffer (pH 5.0), $100 \mu$ moles of sucrose and $0.1 \mathrm{ml}$ of enzyme in a total volume of $1 \mathrm{ml}$ at $30^{\circ} \mathrm{C}$ for $1 \mathrm{~h}$. The reaction was stopped by adding $1 \mathrm{ml}$ of alkaline copper tartrate solution and reducing sugars formed were estimated at $510 \mathrm{~nm}$ using spectrophotometer (Milton Roy) [24]. The protein content in the enzyme extract was determined [25].

\subsection{Extraction and Determination of Water Soluble Carbohydrates (WSC) and Fructans from Internodes}

WSC were extracted by crushing $25 \mathrm{mg}$ of tissue with 10 $\mathrm{ml}$ of distilled water and then incubated at $80^{\circ} \mathrm{C}$ for $1 \mathrm{~h}$. The mixture was then centrifuged at $10,000 \mathrm{~g}$ for $15 \mathrm{~min}$ and the supernatant was taken for estimation. WSC were determined by using the reactions with phenol and sul- 
phuric acid [26]. Fructans were determined, after destroying free fructose by adding $0.5 \mathrm{ml}$ of $30 \% \mathrm{NaOH}$ to $0.5 \mathrm{ml}$ of sugar extract and keeping the mixture in boiling water bath for $10 \mathrm{~min}$. Thereafter fructans were estimated by using resorcinol and $\mathrm{HCl}$ [27].

\section{Results}

The effect of drought on stem reserve mobilization of PBW343 and C306 cultivars was studied by analyzing the dry matter and carbohydrate composition of internodes along with sink activity of grains.

\subsection{Effect of Drought on Biomass, Mobilized Dry Matter and Mobilization Efficiency of Inter Nodes}

Drought induced a significant reduction in the biomass of stem internodes of sensitive cultivar as compared to those of tolerant one (Table 1). The mean biomass of all the internodes of sensitive cultivar were reduced whereas only the apical and peduncle internodes of tolerant cultivar showed reduced mean biomass, under stress conditions. The stressed plants of sensitive cultivar showed higher reduction in the mean biomass of apical and peduncle internodes ( $52 \%$ and $61 \%$ respectively) than those of tolerant one, which showed only 33-36\% decrease, when compared to their respective controls (Table 1). In addition, the mobilized dry matter of internodes and the differences between post anthesis maximum and minimum weight were higher in the tolerant cultivar as compared to the sensitive one, both under control as well as stress conditions. Mobilization efficiency of dry matter, estimated as the ratio of mobilized dry matter to maximum weight was also higher in all the internodes of tolerant cultivar than that of sensitive one, under both control and drought conditions (Table 1). The peduncle internodes of tolerant cultivar showed the maximum mobilization efficiency under drought conditions (Table 1).

\subsection{Effect of Drought on Moisture Content of Internodes}

The data on the percentage of moisture content of internodes showed that drought caused in higher mobilization of stem reserves, particularly from the upper internodes (apical and peduncle) of tolerant cultivar as compared to those of sensitive one (Table 2).

\subsection{Effect of Drought on Moisture Content and Yield of Grains}

The analysis of grain moisture content showed that the sensitive cultivar attained maturity much earlier compared to the tolerant one, under both control and stress conditions (Table 3). Mean grain yield of sensitive cultivar was $32.5 \pm 2.0$ and $18.5 \pm 2.1$ for control and stressed plants respectively. The tolerant cultivar had $25.7 \pm 1.3$ and $19.0 \pm 1.7$ grains per spike for control and stressed plants respectively. Drought induced approximately $43 \%$ decrease in grain yield (number of grains per spike) of sensitive cultivar and $26 \%$ decrease in grain yield of tolerant one when compared each cultivar with own respective control.

Table 1. Effect of withholding irrigation at 95 DAS stage on biomass (mg, mobilized dry matter (mg) and mobilization efficiency (ME) of stem internodes of PBW 343 and C306 cultivars.

\begin{tabular}{|c|c|c|c|c|c|c|c|c|}
\hline \multirow{2}{*}{$\begin{array}{l}\text { Days after } \\
\text { anthesis }\end{array}$} & \multicolumn{4}{|c|}{ PBW343 } & \multicolumn{4}{|c|}{ C306 } \\
\hline & Basal & Middle & Apical & Peduncle & Basal & Middle & Apical & Peduncle \\
\hline 0 & $\begin{array}{l}115 \pm 18 \\
(95 \pm 12)\end{array}$ & $\begin{array}{l}124 \pm 20 \\
(72 \pm 10)\end{array}$ & $\begin{array}{c}125 \pm 12 \\
(63 \pm 7)\end{array}$ & $\begin{array}{l}122 \pm 14 \\
(52 \pm 10)\end{array}$ & $\begin{array}{c}150 \pm 10 \\
(132 \pm 11)\end{array}$ & $\begin{array}{c}111 \pm 30 \\
(133 \pm 13)\end{array}$ & $\begin{array}{c}153 \pm 21 \\
(113 \pm 20)\end{array}$ & $\begin{array}{c}123 \pm 10 \\
(115 \pm 20)\end{array}$ \\
\hline 7 & $\begin{array}{l}112 \pm 20 \\
(94 \pm 10)\end{array}$ & $\begin{array}{l}142 \pm 30 \\
(80 \pm 12)\end{array}$ & $\begin{array}{l}183 \pm 24 \\
(75 \pm 21)\end{array}$ & $\begin{array}{l}135 \pm 32 \\
(50 \pm 12)\end{array}$ & $\begin{array}{c}162 \pm 18 \\
(127 \pm 10)\end{array}$ & $\begin{array}{c}163 \pm 13 \\
(125 \pm 20)\end{array}$ & $\begin{array}{c}184 \pm 24 \\
(90 \pm 9)\end{array}$ & $\begin{array}{c}200 \pm 30 \\
(100 \pm 21)\end{array}$ \\
\hline 14 & $\begin{array}{l}109 \pm 29 \\
(90 \pm 15)\end{array}$ & $\begin{array}{l}130 \pm 15 \\
(77 \pm 13)\end{array}$ & $\begin{array}{l}145 \pm 19 \\
(73 \pm 19)\end{array}$ & $\begin{array}{l}127 \pm 13 \\
(48 \pm 10)\end{array}$ & $\begin{array}{c}92 \pm 12 \\
(123 \pm 14)\end{array}$ & $\begin{array}{c}112 \pm 15 \\
(117 \pm 14)\end{array}$ & $\begin{array}{l}133 \pm 30 \\
(85 \pm 12)\end{array}$ & $\begin{array}{l}132 \pm 15 \\
(89 \pm 11)\end{array}$ \\
\hline 28 & $\begin{array}{c}95 \pm 16 \\
(85 \pm 12)\end{array}$ & $\begin{array}{c}110 \pm 12 \\
(68 \pm 7)\end{array}$ & $\begin{array}{l}128 \pm 22 \\
(67 \pm 20)\end{array}$ & $\begin{array}{c}112 \pm 21 \\
(43 \pm 9)\end{array}$ & $\begin{array}{c}80 \pm 13 \\
(108 \pm 21)\end{array}$ & $\begin{array}{c}84 \pm 6 \\
(98 \pm 10)\end{array}$ & $\begin{array}{l}115 \pm 10 \\
(77 \pm 11)\end{array}$ & $\begin{array}{c}105 \pm 9 \\
(68 \pm 10)\end{array}$ \\
\hline 42 & $\begin{array}{l}81 \pm 10 \\
(82 \pm 9)\end{array}$ & $\begin{array}{l}101 \pm 11 \\
(63 \pm 10)\end{array}$ & $\begin{array}{l}120 \pm 10 \\
(60 \pm 10)\end{array}$ & $\begin{array}{c}100 \pm 15 \\
(40 \pm 7)\end{array}$ & $\begin{array}{c}70 \pm 10 \\
(101 \pm 17)\end{array}$ & $\begin{array}{c}62 \pm 12 \\
(72 \pm 10)\end{array}$ & $\begin{array}{c}91 \pm 11 \\
(70 \pm 13)\end{array}$ & $\begin{array}{c}80 \pm 9 \\
(53 \pm 13)\end{array}$ \\
\hline $\begin{array}{c}\text { Mean } \\
\text { Biomass }\end{array}$ & $\begin{array}{l}100 \\
(88)\end{array}$ & $\begin{array}{l}118 \\
(71)\end{array}$ & $\begin{array}{l}137 \\
(67)\end{array}$ & $\begin{array}{l}117 \\
(45)\end{array}$ & $\begin{array}{c}102 \\
(116)\end{array}$ & $\begin{array}{c}100 \\
(105)\end{array}$ & $\begin{array}{l}129 \\
(84)\end{array}$ & $\begin{array}{l}121 \\
(80)\end{array}$ \\
\hline $\begin{array}{l}\text { Mobilized dry } \\
\text { matter }\end{array}$ & $\begin{array}{c}34 \\
(13)\end{array}$ & $\begin{array}{c}41 \\
(17)\end{array}$ & $\begin{array}{c}63 \\
(15)\end{array}$ & $\begin{array}{c}35 \\
(12)\end{array}$ & $\begin{array}{c}92 \\
(31)\end{array}$ & $\begin{array}{l}101 \\
(61)\end{array}$ & $\begin{array}{c}93 \\
(43)\end{array}$ & $\begin{array}{l}120 \\
(62)\end{array}$ \\
\hline $\mathrm{ME}(\%)$ & $\begin{array}{c}29.6 \\
(13.7)\end{array}$ & $\begin{array}{c}28.9 \\
(21.2)\end{array}$ & $\begin{array}{c}34.4 \\
(20.0)\end{array}$ & $\begin{array}{c}25.9 \\
(23.1)\end{array}$ & $\begin{array}{c}56.8 \\
(23.5)\end{array}$ & $\begin{array}{c}62.0 \\
(45.9)\end{array}$ & $\begin{array}{c}50.5 \\
(38.0)\end{array}$ & $\begin{array}{c}60.0 \\
(53.0)\end{array}$ \\
\hline
\end{tabular}

Data represent mean \pm S.D. of four replicates. Values without parentheses are for control plants and those with parentheses are for water deficit plants. 
Table 2. Effect of withholding irrigation at 95 DAS stage on moisture content (\%) of stem internodes of PBW 343 and C306 cultivars.

\begin{tabular}{ccccccccc}
\hline \multirow{2}{*}{$\begin{array}{c}\text { Days after } \\
\text { anthesis }\end{array}$} & \multicolumn{9}{c}{ PBW343 } & \multicolumn{3}{c}{ C306 } \\
\cline { 2 - 8 } & Basal & Middle & Apical & Peduncle & Basal & Middle & Apical & Peduncle \\
\hline \multirow{2}{*}{0} & $52.4 \pm 3.2$ & $50.3 \pm 4.5$ & $52.2 \pm 8.3$ & $48.6 \pm 3.8$ & $58.5 \pm 0.9$ & $63.2 \pm 3.3$ & $70.0 \pm 2.5$ & $74.2 \pm 0.8$ \\
& $(41.1 \pm 2.7)$ & $(40.4 \pm 4.6)$ & $(46.4 \pm 6.4)$ & $(49.5 \pm 5.7)$ & $(51.9 \pm 2.1)$ & $(55.6 \pm 2.1)$ & $(61.0 \pm 2.9)$ & $(65.5 \pm 2.5)$ \\
& $55.1 \pm 2.7$ & $51.5 \pm 2.2$ & $53.3 \pm 1.2$ & $54.1 \pm 1.3$ & $54.3 \pm 1.6$ & $53.6 \pm 1.8$ & $51.5 \pm 1.8$ & $55.3 \pm 1.2$ \\
7 & $(29.4 \pm 4.7)$ & $(27.1 \pm 1.2)$ & $(33.1 \pm 3.3)$ & $(19.5 \pm 2.9)$ & $(38.7 \pm 3.9)$ & $(36.6 \pm 2.3)$ & $(33.9 \pm 3.4)$ & $(30.2 \pm 2.5)$ \\
& $58.0 \pm 1.5$ & $59.2 \pm 1.2$ & $59.2 \pm 1.2$ & $58.5 \pm 0.9$ & $51.0 \pm 4.0$ & $51.3 \pm 3.9$ & $51.4 \pm 2.3$ & $55.2 \pm 0.6$ \\
14 & $(24.5 \pm 0.4)$ & $(25.5 \pm 3.2)$ & $(28.0 \pm 4.1)$ & $(16.7 \pm 1.7)$ & $(29.7 \pm 5.3)$ & $(27.2 \pm 2.8)$ & $(28.5 \pm 7.4)$ & $(22.9 \pm 14.4)$ \\
& $55.2 \pm 9.0$ & $56.2 \pm 8.2$ & $51.0 \pm 5.7$ & $46.3 \pm 10$ & $49.5 \pm 4.1$ & $50.4 \pm 3.3$ & $50.3 \pm 6.3$ & $50.5 \pm 1.3$ \\
28 & $(5.4 \pm 0.1)$ & $(9.8 \pm 1.9)$ & $(7.5 \pm 2.2)$ & $(6.7 \pm 1.0)$ & $(18.1 \pm 1.5)$ & $(19.4 \pm 0.4)$ & $(13.5 \pm 4.5)$ & $(10.3 \pm 0.9)$ \\
& $1.2 \pm 0.3$ & $1.8 \pm 0.9$ & $1.1 \pm 0.4$ & $1.8 \pm 0.1$ & $10.1 \pm 0.5$ & $11.6 \pm 1.6$ & $6.7 \pm 1.2$ & $5.6 \pm 1.1$ \\
42 & $(0)$ & $(0)$ & $(0)$ & $(0)$ & $(11.7 \pm 3.0)$ & $(4.6 \pm 1.1)$ & $(2.2 \pm 0.6)$ & $(2.0 \pm 0.8)$ \\
\hline
\end{tabular}

Data represent mean \pm S.D. of four replicates. Values without parentheses are for control plants and those with parentheses are for water deficit plants.

Table 3. Effect of withholding irrigation at 95 DAS stage on moisture content (\%) of grains of PBW343 and C306 cultivars.

\begin{tabular}{ccccccc}
\hline \multirow{2}{*}{ Cultivar } & \multicolumn{9}{c}{ Days after anthesis } \\
\cline { 2 - 7 } & 7 & 14 & 21 & 28 & 35 & 42 \\
\hline \multirow{2}{*}{ PBW 343 } & $69.7 \pm 1.5$ & $51.9 \pm 2.9$ & $45.5 \pm 0.9$ & $29.2 \pm 1.8$ & $5.7 \pm 0.3$ & $1.5 \pm 0.3$ \\
& $(60.9 \pm 4.0)$ & $(48.5 \pm 0.6)$ & $(7.7 \pm 2.4)$ & $(5.5 \pm 0.6)$ & $(5.0 \pm 0.8)$ & $(1.0 \pm 0.1)$ \\
C306 & $70.8 \pm 0.4$ & $64.5 \pm 1.5$ & $49.7 \pm 0.7$ & $43.9 \pm 2.4$ & $24.1 \pm 2.4$ & $4.5 \pm 0.9$ \\
& $(65.5 \pm 0.9)$ & $(51.4 \pm 4.8)$ & $(29.9 \pm 2.0)$ & $(9.6 \pm 0.8)$ & $(6.6 \pm 1.5)$ & $(2.4 \pm 0.6)$ \\
\hline
\end{tabular}

Data represent mean \pm S.D. of four replicates. Values without parentheses are for control plants and those with parentheses are for water deficit plants.

\subsection{Effect of Drought on Sucrose Synthase and Acid Invertase Activity of Grains}

The grains of sensitive cultivar showed the maximum of SS at 14 DAA, then it declined reaching negligible values at 35DAA stage. The tolerant cultivar had the maximum SS activity at 7 DAA, then it declined gradually reaching negligible values at 35DAA (Table 4). When drought was applied, SS activity increased in the grains of both the cultivars, but the levels were significantly higher in the tolerant one (Table 4). The sensitive cultivar had very low SS activity at 21 DAA which then declined reaching a negligible value at 28 DAA (Table 4). In other words, SS activity was higher in the grains of tolerant cultivar than in that of sensitive one, both under control and stress conditions (Table 4).

AI activity of grains was observed to be comparable in control plants of both the cultivars at 7 and 14 DAA and then declined, reaching negligible values at 21 DAA (Table 4). Under stress conditions, acid invertase activity was observed to be a little higher in the grains of sensitive cultivar at 7 DAA (Table 4).

\subsection{Effect of Drought on Carbohydrate Status of the Two Cultivars}

The content of water soluble carbohydrate (WSC) in the internodes of control plants of tolerant cultivar was higher than those of sensitive one, at all the growth stages examined (Table 5). When drought was applied by withholding irrigation, the mobilized WSC content remained higher in the internodes of tolerant cultivar compared to the sensitive one (Table 5). Fructan content in the internodes of tolerant cultivar was also higher than the sensitive one, under both control and stress conditions (Table 6). The content of mobilized fructan was higher in all the internodes of the control and drought stressed plants of tolerant cultivar compared to the sensitive one (Table 6).

\section{Discussion}

The two wheat cultivars showed significantly variable agronomical and biochemical parameters which attributed to their differential response to drought conditions.

PBW 343, the sensitive double dwarf cultivar showed relatively little tolerance against drought as compared to C306, the tall, tolerant cultivar. It could be inferred that when drought was applied by withholding irrigation at 95 DAS stage, i.e., just five days before the initiation of anthesis, the dry matter accumulation in the internodes of sensitive cultivar was much more affected than those of tolerant one, leading to a decrease in mean biomass of the internodes of sensitive cultivar. Under optimal growing conditions, carbon assimilation rates are high and a 
Table 4. Effect of withholding irrigation at 95 DAS stage on specific activity of sucrose synthase and acid invertase (nmole sucrose hydrolysed $\mathrm{mg}^{-1}$ protein $\mathrm{min}^{-1}$ ) in grains of PBW343 and C306 cultivars.

\begin{tabular}{|c|c|c|c|c|}
\hline \multirow{2}{*}{ Enzyme } & \multicolumn{4}{|c|}{ Days after anthesis } \\
\hline & 7 & 14 & 21 & 28 \\
\hline \multicolumn{5}{|c|}{ Sucrose synthase } \\
\hline PBW343 & $\begin{array}{c}16.6 \pm 0.05 \\
(24.5 \pm 0.09)\end{array}$ & $\begin{array}{c}40.2 \pm 1.0 \\
(61.9 \pm 7.4)\end{array}$ & $\begin{array}{l}31.4 \pm 4.7 \\
(5.4 \pm 0.8)\end{array}$ & $\begin{array}{c}5.0 \pm 0.1 \\
\text { (negligible) }\end{array}$ \\
\hline C306 & $\begin{array}{c}52.8 \pm 3.8 \\
(89.7 \pm 3.6)\end{array}$ & $\begin{array}{c}37.4 \pm 3.9 \\
(23.5 \pm 4.0)\end{array}$ & $\begin{array}{c}32.8 \pm 2.4 \\
(19.7 \pm 1.7)\end{array}$ & $\begin{array}{c}8.1 \pm 0.01 \\
(1.2 \pm 0.02)\end{array}$ \\
\hline \multicolumn{5}{|c|}{ Acid Invertase } \\
\hline PBW343 & $\begin{array}{l}0.96 \pm 0.02 \\
(9.8 \pm 0.08)\end{array}$ & $\begin{array}{c}1.26 \pm 0.05 \\
(1.89 \pm 0.03)\end{array}$ & $\begin{array}{l}\text { Negligible } \\
\text { (Negligible) }\end{array}$ & $\begin{array}{l}\text { Negligible } \\
\text { (Negligible) }\end{array}$ \\
\hline C306 & $\begin{array}{l}1.55 \pm 0.04 \\
(2.0 \pm 0.05)\end{array}$ & $\begin{array}{c}1.69 \pm 0.06 \\
(1.88 \pm 0.42)\end{array}$ & $\begin{array}{l}\text { Negligible } \\
\text { (Negligible) }\end{array}$ & $\begin{array}{l}\text { Negligible } \\
\text { (Negligible) }\end{array}$ \\
\hline
\end{tabular}

Data represent mean \pm S.D. of three replicates. Values without parantheses are for control plants and those with parantheses are for water deficit plants. Activity was negligible at 35 and 42 DAA.

Table 5. Effect of withholding irrigation at 95 DAS stage on water soluble carbohydrate (WSC) content (mg/g dry wt.) of stem internodes of PBW 343 and C306 cultivars.

\begin{tabular}{|c|c|c|c|c|c|c|c|c|}
\hline \multirow{2}{*}{$\begin{array}{l}\text { Days after } \\
\text { anthesis }\end{array}$} & \multicolumn{4}{|c|}{ PBW343 } & \multicolumn{4}{|c|}{ C306 } \\
\hline & Basal & Middle & Apical & Peduncle & Basal & Middle & Apical & Peduncle \\
\hline 0 & $\begin{array}{c}310 \pm 83 \\
(186 \pm 32)\end{array}$ & $\begin{array}{c}287 \pm 19 \\
(152 \pm 27)\end{array}$ & $\begin{array}{c}272 \pm 43 \\
(162 \pm 37)\end{array}$ & $\begin{array}{c}170 \pm 18 \\
(137 \pm 12)\end{array}$ & $\begin{array}{c}310 \pm 10 \\
(315 \pm 35)\end{array}$ & $\begin{array}{c}307 \pm 30 \\
(263 \pm 14)\end{array}$ & $\begin{array}{c}170 \pm 24 \\
(250 \pm 22)\end{array}$ & $\begin{array}{c}170 \pm 14 \\
(270 \pm 24)\end{array}$ \\
\hline 7 & $\begin{array}{c}210 \pm 41 \\
(128 \pm 24)\end{array}$ & $\begin{array}{c}273 \pm 24 \\
(105 \pm 15)\end{array}$ & $\begin{array}{c}317 \pm 18 \\
(115 \pm 04)\end{array}$ & $\begin{array}{c}210 \pm 19 \\
(130 \pm 10)\end{array}$ & $\begin{array}{c}425 \pm 96 \\
(251 \pm 25)\end{array}$ & $\begin{array}{c}415 \pm 22 \\
(183 \pm 19)\end{array}$ & $\begin{array}{c}380 \pm 28 \\
(125 \pm 05)\end{array}$ & $\begin{array}{c}260 \pm 18 \\
(133 \pm 20)\end{array}$ \\
\hline 14 & $\begin{array}{c}72 \pm 14 \\
(113 \pm 11)\end{array}$ & $\begin{array}{c}78 \pm 04 \\
(92 \pm 06)\end{array}$ & $\begin{array}{c}108 \pm 24 \\
(142 \pm 14)\end{array}$ & $\begin{array}{c}67 \pm 02 \\
(115 \pm 36)\end{array}$ & $\begin{array}{c}347 \pm 51 \\
(168 \pm 37)\end{array}$ & $\begin{array}{c}391 \pm 46 \\
(152 \pm 12)\end{array}$ & $\begin{array}{c}379 \pm 13 \\
(123 \pm 37)\end{array}$ & $\begin{array}{c}321 \pm 28 \\
(129 \pm 10)\end{array}$ \\
\hline 28 & $\begin{array}{c}24 \pm 03 \\
(106 \pm 28)\end{array}$ & $\begin{array}{c}27 \pm 05 \\
(75 \pm 14)\end{array}$ & $\begin{array}{c}21 \pm 02 \\
(80 \pm 09)\end{array}$ & $\begin{array}{c}33 \pm 06 \\
(96 \pm 13)\end{array}$ & $\begin{array}{c}102 \pm 22 \\
(127 \pm 17)\end{array}$ & $\begin{array}{c}123 \pm 25 \\
(137 \pm 27)\end{array}$ & $\begin{array}{c}72 \pm 20 \\
(110 \pm 15)\end{array}$ & $\begin{array}{c}60 \pm 02 \\
(121 \pm 20)\end{array}$ \\
\hline 42 & $\begin{array}{c}20 \pm 03 \\
(89 \pm 21)\end{array}$ & $\begin{array}{c}25 \pm 02 \\
(60 \pm 12)\end{array}$ & $\begin{array}{c}17 \pm 03 \\
(48 \pm 12)\end{array}$ & $\begin{array}{c}24 \pm 04 \\
(57 \pm 11)\end{array}$ & $\begin{array}{c}68 \pm 10 \\
(100 \pm 23)\end{array}$ & $\begin{array}{c}56 \pm 02 \\
(99 \pm 24)\end{array}$ & $\begin{array}{c}32 \pm 04 \\
(89 \pm 16)\end{array}$ & $\begin{array}{c}34 \pm 07 \\
(90 \pm 16)\end{array}$ \\
\hline $\begin{array}{l}\text { Mobilized } \\
\text { WSC (mg/g } \\
\text { dry Wt.) }\end{array}$ & $\begin{array}{l}290 \\
(97)\end{array}$ & $\begin{array}{l}262 \\
(92)\end{array}$ & $\begin{array}{c}300 \\
(114)\end{array}$ & $\begin{array}{l}187 \\
(80)\end{array}$ & $\begin{array}{c}357 \\
(215)\end{array}$ & $\begin{array}{c}359 \\
(164)\end{array}$ & $\begin{array}{c}348 \\
(161)\end{array}$ & $\begin{array}{c}287 \\
(180)\end{array}$ \\
\hline
\end{tabular}

Data represent mean \pm S.D. of four replicates. Values without parentheses are for control plants and those with parentheses are for water deficit plants.

proportion of assimilates is allocated to stem storage. When carbon assimilation is reduced by stress, storage in stems also gets affected [28].

The stress tolerance efficiency of cereals was dependent not only on the assimilation of stem reserves but also on the effective partitioning of these reserves to the grains $[29,30]$. Higher mobilization efficiency resulted in better utilization of pre-anthesis stored reserves from the internodes of tolerant cultivar. Water deficit induced reallocation of $75-92 \%$ of preanthesis ${ }^{14} \mathrm{C}$ stored in stem and sheath to grains has been reported in literature [10].

Reserve storage mainly occur as water soluble carbohydrates (WSC) which can accumulate in wheat stems to more than $40 \%$ of total stem dry weight [31]. WSCs in wheat stems are mainly composed of fructans, sucrose, glucose and fructose, with fructans being the major component [32]. WSC content and fructan content, which were manifold higher in the internodes of drought tolerant cultivar than those of sensitive one could be due to greater storage capacity of the taller cultivar. The capacity for maintaining large storage in stems appeared to be a genetically controlled constitutive trait $[15,33]$. Taller cultivars have been reported to have greater stem storage [1]. The Rht-B1b and Rht-D1b dwarfing genes of wheat were found to reduce reserve storage (fructans) by $35 \%$ and $39 \%$ respectively, as a consequence of $21 \%$ reduction in stem length [34]. WSC levels were reported to be positively correlated with mRNA expression levels of fructan synthesizing enzymes, e.g., Suc: Suc 1-fructosyltransferase (1-SST) and Suc: fructan 6- fructosyltrans- 
Table 6 . Effect of withholding irrigation at 95 DAS stage on fructan content (mg/g dry wt.) of stem internodes of PBW 343 and C306 cultivars.

\begin{tabular}{|c|c|c|c|c|c|c|c|c|}
\hline \multirow{2}{*}{$\begin{array}{l}\text { Days after } \\
\text { anthesis }\end{array}$} & \multicolumn{4}{|c|}{ PBW343 } & \multicolumn{4}{|c|}{ C306 } \\
\hline & Basal & Middle & Apical & Peduncle & Basal & Middle & Apical & Peduncle \\
\hline 0 & $\begin{array}{c}200 \pm 08 \\
(71 \pm 5)\end{array}$ & $\begin{array}{l}160 \pm 16 \\
(71 \pm 13)\end{array}$ & $\begin{array}{l}224 \pm 16 \\
(87 \pm 10)\end{array}$ & $\begin{array}{l}155 \pm 27 \\
(88 \pm 16)\end{array}$ & $\begin{array}{c}216 \pm 56 \\
(310 \pm 37)\end{array}$ & $\begin{array}{c}277 \pm 17 \\
(262 \pm 40)\end{array}$ & $\begin{array}{l}110 \pm 22 \\
(232 \pm 56)\end{array}$ & $\begin{array}{c}99 \pm 14 \\
(123 \pm 40)\end{array}$ \\
\hline 7 & $\begin{array}{c}131 \pm 23 \\
(120 \pm 7)\end{array}$ & $\begin{array}{c}171 \pm 32 \\
(92 \pm 14)\end{array}$ & $\begin{array}{c}261 \pm 20 \\
(99 \pm 7)\end{array}$ & $\begin{array}{c}142 \pm 19 \\
(103 \pm 8)\end{array}$ & $\begin{array}{c}405 \pm 38 \\
(196 \pm 52)\end{array}$ & $\begin{array}{c}408 \pm 36 \\
(144 \pm 16)\end{array}$ & $\begin{array}{c}336 \pm 51 \\
(113 \pm 23)\end{array}$ & $\begin{array}{c}224 \pm 25 \\
(122 \pm 22)\end{array}$ \\
\hline 14 & $\begin{array}{c}16 \pm 01 \\
(55 \pm 08)\end{array}$ & $\begin{array}{c}24 \pm 01 \\
(59 \pm 16)\end{array}$ & $\begin{array}{c}44 \pm 15 \\
(92 \pm 22)\end{array}$ & $\begin{array}{c}24 \pm 01 \\
(80 \pm 02)\end{array}$ & $\begin{array}{c}301 \pm 51 \\
(149 \pm 31)\end{array}$ & $\begin{array}{c}362 \pm 46 \\
(128 \pm 16)\end{array}$ & $\begin{array}{c}352 \pm 13 \\
(109 \pm 14)\end{array}$ & $\begin{array}{l}308 \pm 28 \\
(118 \pm 8)\end{array}$ \\
\hline 28 & $\begin{array}{c}10 \pm 01 \\
(28 \pm 03)\end{array}$ & $\begin{array}{c}10 \pm 01 \\
(24 \pm 06)\end{array}$ & $\begin{array}{c}09 \pm 01 \\
(43 \pm 04)\end{array}$ & $\begin{array}{c}12 \pm 2 \\
(48 \pm 3)\end{array}$ & $\begin{array}{c}30 \pm 4 \\
(100 \pm 9)\end{array}$ & $\begin{array}{c}48 \pm 11 \\
(100 \pm 17)\end{array}$ & $\begin{array}{c}27 \pm 7 \\
(99 \pm 4)\end{array}$ & $\begin{array}{c}40 \pm 9 \\
(112 \pm 10)\end{array}$ \\
\hline 42 & $\begin{array}{c}5 \pm 0.4 \\
(17 \pm 1)\end{array}$ & $\begin{array}{c}5 \pm 0.9 \\
(16 \pm 2)\end{array}$ & $\begin{array}{c}5 \pm 0.3 \\
(40 \pm 10)\end{array}$ & $\begin{array}{c}4 \pm 0.1 \\
(37 \pm 9)\end{array}$ & $\begin{array}{c}18 \pm 4 \\
(36 \pm 8)\end{array}$ & $\begin{array}{c}14 \pm 5 \\
(43 \pm 5)\end{array}$ & $\begin{array}{c}13 \pm 4 \\
(52 \pm 5)\end{array}$ & $\begin{array}{c}11 \pm 2 \\
(34 \pm 4)\end{array}$ \\
\hline $\begin{array}{c}\text { Mobilized } \\
\text { fructan } \\
\text { content }\end{array}$ & $\begin{array}{c}195 \\
(103)\end{array}$ & $\begin{array}{l}166 \\
(76)\end{array}$ & $\begin{array}{l}256 \\
(59)\end{array}$ & $\begin{array}{l}151 \\
(66)\end{array}$ & $\begin{array}{c}387 \\
(274)\end{array}$ & $\begin{array}{c}394 \\
(219)\end{array}$ & $\begin{array}{c}339 \\
(180)\end{array}$ & $\begin{array}{l}297 \\
(89)\end{array}$ \\
\hline
\end{tabular}

Data represent mean \pm S.D. of four replicates. Values without parentheses are for control plants and those with parentheses are for water deficit plants.

ferase (6-SFT) and these enzymes were differentially expressed among genotypes differing in WSC concentrations [15]. High fructan depolymerization in the internodes of tolerant cultivar, under drought conditions suggested a degree of osmotic adjustment leading to a possible mechanism of protection against dehydration. It might, therefore, be proposed that the effectively higher mobilization of fructans, under drought conditions, helped the tolerant cultivar in coping stress conditions.

While the size of storage is pre-eminent, the size of sink and its capacity to utilize the imported carbon is also important for allowing grain filling from stem reserves. In drought conditions, the enhanced mobilization of stem reserves, is directly linked to the increased demand of these reserves by the ear. Kernels are very strong sinks for carbohydrates, during grain filling period [35]. High levels of enzymes involved in the unloading of assimilates in the sink through cleavage of sucrose would increase the sink capacity by lowering the local concentration of sucrose, thereby generating a gradient that allows further unloading of sucrose from phloem [36]. The enhanced SS activity in the grains of drought stressed plants of tolerant cultivar as compared to those of sensitive one increased the sink strength and attributed towards faster remobilization of assimilates to the grains. Sucrose synthase activity is therefore regarded as biological marker of sink strength [37]. Higher activity of SS in wheat grains subjected to water deficit conditions has been reported earlier [38,39]. AI activity was relatively little higher in the grains of sensitive cultivar as compared to those of tolerant one, under stress conditions and thus could not contribute towards effectively increasing the sink strength of sensitive cultivar. The higher sink activity of tolerant cultivar, under drought condi- tions, thus induced higher mobilization of stem reserves to the grains, thereby restricting a heavy decrease in grain yield (in terms of number of grains per spike) as was observed for sensitive cultivar. Yield is the most important economic trait, and grain production is the main selection criterion for drought resistance of wheat [40]. The current findings in relation to water stress and the earlier observations [14] tend to support the suggestion that drought tolerant wheat cultivars are capable of synthesizing, storing and mobilizing high concentration of water soluble carbohydrates from their stems and have stronger sink activity as compared to drought sensitive cultivars, under water stress conditions. This would enable the tolerant cultivar to exhibit improved grain yield even during stress conditions. It was suggested that under stress conditions the tolerant genotypes activated their protection mechanisms faster and more efficiently than the sensitive ones [3].

Water stress induced shortening of grain filling duration with smaller kernels at maturity was earlier reported [41]. Grains of sensitive cultivar attained maturity much earlier as compared to tolerant one, both under control and drought conditions. It was reported that during drought conditions, the rate at which stem reserves were mobilized to the grains was not sufficiently high to compensate for the reduction in grain filling period [33]. Therefore, genotypes with longer grain maturation period appeared to have an advantage in this respect. It is proposed that longer duration of grain maturation in case of drought tolerant cultivar allows greater utilization of stem reserves as compared to sensitive one, under stress conditions.

We can conclude that the higher capability of the tall wheat cultivar, C306 to tolerate drought stress is due to 
its ability of synthesizing and storing larger concentration of fructans in its stems coupled with higher mobilization efficiency, stronger sink activity and longer duration of grain maturation under water deficit conditions, suggesting its use in breeding program or in drought area where other sensitive wheat cultivars may be severely affected.

\section{Acknowledgements}

Thanks are due to University Grants Commission, New Delhi for providing grant for this work.

\section{REFERENCES}

[1] A. Blum, "Improving Wheat Grain Filling under Stress by Stem Reserve Utilization," Euphytica, Vol. 100, No.1, 1998, pp. 77-83. doi:10.1023/A:1018303922482

[2] B. Ehdaie and J.G. Waines, "Adaptation of Landrace and Improved Spring Wheat Genotypes to Stress Environments," Journal of Genetics and Breeding, Vol. 43, 1989, pp. 151-156.

[3] A. Aprile, A.M. Mastrangelo, A.M.D. Leonardis, G. Galiba, E. Roncaglia, F. Ferrari, L.D. Bellis, L. Turchi, G. Giuliano and L. Cattivelli, "Transcriptional Profiling in Response to Terminal Drought Stress Reveals Differential Responses along the Wheat Genome", BMC Genomics, Vol. 10:, 2009, p. 279.

doi:10.1186/1471-2164-10-279

[4] M.P.Reynolds, A.M. Kazi and M. Sawkins, "Prospects for Utilizing Plant Adaptive Mechanisms to Improve Wheat and Other Crops in Drought and Salinity Prone Environments," Annals in Applied Biology, Vol. 146, No. 2, 2005, pp. 239-259. doi:10.1111/j.1744-7348.2005.040058.x

[5] R.Ortiz, M. Iwanaga, M.P. Reynolds, H. Wu and J.H. Crouch, "Overview on Crop Genetic Engineering for Drought Prone Environments," CIMMYT, Vol. 4, No. 1, 2007, pp. 1-30.

[6] D. Bartels and R. Sunkar, "Drought and Salt Tolerance in Plants", Critical Reviews in Plant Sciences, Vol. 24, No. 1, 2005, pp.23-58. doi:10.1080/07352680590910410

[7] J. Yang, J. Zhang, Z. Huang, Q. Zhu and L.Wang, "Remobilization of Carbon Reserves is Improved by Controlled Soil Drying During Grain Filling in Wheat," Crop Science, Vol. 40, No. 6, 2000, pp. 1645-1655. doi:10.2135/cropsci2000.4061645x

[8] J. Zhang, X. Sui, B. Li, B. Su, J. Li and D. Zhou, "An Improved Water Use Efficiency for Winter Wheat Grown under Reduced Irrigation," Field Crop Research, Vol. 59, No. 2, 1998, pp. 91-98.

doi:10.1016/S0378-4290(98)00104-X

[9] T. Gebbing and S. Schnyder, "Pre-anthehsis Reserve Utilization for Protein and Carbohydrate Synthesis in Grains of Wheat," Plant Physiology, Vol. 121, No. 3, 1999, pp. 871-878. doi:10.1104/pp.121.3.871

[10] J. Yang, J. Zhang, Z. Wang, Q. Zhu and W. Wang, "Hormonal Changes in the Grains of Rice Subjected to
Water Stress during Grain Filling," Plant Physiology, Vol. 127, No.1, 2001, pp. 315-323. doi:10.1104/pp.127.1.315

[11] J. Yang, J. Zhang, Z. Wang, Q. Zhu and L. Liu, "Involvement of Abscisic Acid and Cytokinins in the Senescence and Remobilization of Carbon Reserves in Wheat Subjected to Water Stress during Grain Filling", Plant Cell and Environment, Vol. 26, No.10, 2003, pp. 1621-1631. doi:10.1046/j.1365-3040.2003.01081.x

[12] I.F. Wardlaw and J. Willenbrink, "Carbohydrate Storage and Mobilization by the Culm of Wheat between Heading and Grain Maturity: the Relation to Sucrose Synthase and Sucrose Phosphate Synthase," Australian Journal of Plant Physiology, Vol. 21, No. 3, 1994, pp. 255-271. doi:10.1071/PP9940255

[13] J. Yang, J. Zhang, Z. Wang, Q. Zhu and L. Liu, "Water Deficit Induced Senescence and Its Relationship to the Remobilization of Pre Stored Carbon in Wheat during Grain Filling," Agronomy Journal, Vol. 93, No. 1, 2001, pp. 196-206. doi:10.2134/agronj2001.931196x

[14] E. A. Conocono, "Improving Yield of Wheat Experiencing Post Anthesis Water Deficits through the Use of Shoot Carbohydrate Reserves", 2002, Ph.D. thesis, University of Western Australia, Australia.

[15] G. P. Xue, C. L. McIntyre, C. L. D. Jenkins, D. Glassop, A. F. Van Herwaarden and R. Shorter, "Molecular Dissection of Variation in Carbohydrate Metabolism Related to Water Soluble Carbohydrate Accumulation in Stems of Wheat," Plant Physiology, Vol. 146, No. 2, 2008, pp. 441-454. doi:10.1104/pp.107.113076

[16] F. Volaire and F. Lelievre, "Production, Persistence and Water Soluble Carbohydrate Accumulation in 21 Contrasting Populations of Dactylis glomerata L. Subjected to Severe Drought Stress in the South of France," Australian Journal of Agricultural Research, Vol. 48, No. 6, 1997, pp. 933-944. doi:10.1071/A97004

[17] D. E. Goggin and T. L. Setter, "Fructosyltransferase Activity and Fructan Accumulation during Development in Wheat Exposed to Terminal Drought," Functional Plant Biology, Vol. 31, No. 1, 2004, pp. 11-21. doi:10.1071/FP03123

[18] B. Ehdaie, G. A. Alloush, M. A. Madore and J. G. Waines, "Genotypic Variation for Stem Reserves and Mobilization in Wheat. I. Post Anthesis Changes in Internode Dry Matter," Crop Science, Vol. 46, No. 2, 2006, pp. 735-746. doi:10.2135/cropsci2005.04-0033

[19] B. Ehdaie B, G. A. Alloush, M. A. Madore and J. G. Waines, "Genotypic Variation for Stem Reserves and Mobilization in Wheat. II. Post Anthesis Changes in internode Water Soluble Carbohydrates," Crop Science, Vol. 46, No. 5, 2006, pp. 2093-2103.

[20] M. R. Shakiba, B. Ehdaie, M. A. Madore and J. G. Waines, "Contribution of Internode Reserves to Grain Yield in a Tall and Semi Dwarf Spring Wheat," Journal of Genetics and Breeding, Vol. 50, 1996, pp.91-100.

[21] K. Kaur, A. K. Gupta and N. Kaur, "Effect of Water Deficit on Carbohydrate Status and Enzymes of Carbohydrate Metabolism in Seedlings of Wheat Cultivars," 
Indian Journal of Biochemistry and Biophysics, Vol. 44, No. 4, 2007, pp. 223-230.

[22] S. Kaur, A. K. Gupta and N. Kaur, "Effect of Kinetin on Starch and Sucrose Metabolizing Enzymes in Salt Stressed Chickpea Seedlings," Biologia Plantarum, Vol. 46, No. 1, 2003, pp. 67-72. doi:10.1023/A:1022310100557

[23] H. B. Krishnan, J. T. Blanchette and T. W. Okita, "Wheat Invertase Characterization of Cell Wall Bound and Soluble Forms," Plant Physiology, Vol. 88, 1985, pp. 241-245. doi:10.1104/pp.78.2.241

[24] S. Kaur, A. K. Gupta and N. Kaur, "Effect of $\mathrm{GA}_{3}$, Kinetin and Indole Acetic Acid on Carbohydrate Metabolism in Chickpea Seedlings Germinating under Water Stress," Plant Growth Regulation, Vol. 30, No. 1, 2000, pp. 61-70. doi:10.1023/A:1006371219048

[25] O. H. Lowry, N. J. Rosebrough, A. L. Farr and R. J. Randall, "Protein Measurement with Folin Phenol Reagent," Journal of Biological Chemistry, Vol. 193, No. 1, 1951, pp. 265-275.

[26] M. Dubois, K. A. Gilles, J. K. Hamilton, P. A. Robers and F. Smith, "Colorimetric Method for Determination of Sugars and Related Substances," Analytical Chemistry, Vol. 28, No. 3, 1956, pp. 350-356. doi:10.1021/ac60111a017

[27] L. M. Williard and M. Slattery, "The Colorimetric Determination of Fructosan in Plant Material," Journal of Bilogical Chemistry, Vol. 157, No. 2, 1945, pp.161-167.

[28] D. J. Davidson and P. M. Chevalier, "Storage and Remobilization of Water Soluble Carbohydrates in Stems of Spring Wheat," Crop Science, Vol. 32, No. 1, 1992, pp. 186-190.

doi:10.2135/cropsci1992.0011183X003200010038x

[29] R. Kumar, A.K. Sarawgi, C. Ramos, S.T. Amarante, A.M. Ismail and L.J. Wade, "Partitioning of Dry Matter during Drought Stress in Rainfed Lowland Rice," Field Crops Research, Vol. 98, No. 1, 2006, pp. 1-11. doi:10.1016/j.fcr.2005.09.015

[30] B. Ehdaie and J. G. Waines, "Genetic Variation for Contribution of Preanthesis Assimilates to Grain Yield," Journal of Genetics and Breeding, Vol. 50, 1996, pp. 47-56.

[31] T. L. Housley, "Role of Fructans Redistributed from Vegetative Tissues in Grain Filling of Wheat and Barley," In AK Gupta, N Kaur, eds, Carbohydrate Reserves in Plants: Synthesis and Regulation, Developments in Crop Science, Vol. 26. Elsevier, Amsterdam, 2000, pp 207-221. doi:10.1016/S0378-519X(00)80011-2

[32] S. A. Ruuska , G. J. Rebetzke, A. F. Van Harwaarden, R.
A. Richards, N. A. Fettell, L. Tabe and C.L.D. Jenkins, "Genotypic Variation in Water Soluble Carbohydrate Accumulation in Wheat", Functional Plant Biology, Vol. 33, No. 9, 2006, pp. 799-809. doi:10.1071/FP06062

[33] A. Blum, B. Sinmena, J. Mayer, G. Golan and L. Shpiler, "Stem Reserve Mobilization Supports Wheat Grain Filling under Heat Stress", Australian Journal of Plant Physiology, Vol. 21, No. 6, 1994, pp. 771-781. doi:10.1071/PP9940771

[34] A. Borrell, L.D. Incoll and M.J. Dalling, "The Influence of the Rht 1 and Rht 2 Alleles on the Deposition and Use of Stem Reserves in Wheat", Annals in Botany, Vol. 71, No. 4, 1993, pp.317-326. doi:10.1006/anbo.1993.1041

[35] H. C. Riffkin, C. M. Duffus and I. C. Bridges, "Sucrose Metabolism during Development of Wheat (Triticum aestivum)," Physiologia Plantarum, Vol. 98, 1995, pp. 123131. doi:10.1034/j.1399-3054.1995.930118.x

[36] J. Liang, J. Zhang and X. Cox, "Grain Sink Strength May be Related to Poor Grain Filling of Indica Japonica Rice (Oryza sativa) Hybrids," Physiologia Plantarum, Vol. 112, No. 4, 2001, pp. 470-477. doi:10.1034/j.1399-3054.2001.1120403.x

[37] A. P. Ranwala and W. B. Miller, "Sucrose Cleaving Enzymes and Carbohydrate Pools in Lilium longiflorum Floral Organs," Physiologia Plantarum, Vol. 103, No. 4, 1998, pp. 541-550. doi:10.1034/j.1399-3054.1998.1030413.x

[38] J. Yang, J. Zhang, Z. Wang, G. Xu and Q. Zhu, “Activities of Key Enzymes in Sucrose to Starch Conversion in Wheat Grains Subjected to Water Deficit during Grain Filling", Plant Physiology, Vol. 135, No. 3, 2004, pp. 1621-1629. doi:10.1104/pp.104.041038

[39] Z. Dai, Y. Yin and Z. Wang, "Activities of Key Enzymes Involved in Starch Synthesis in Grains of Wheat under Different Irrigation Patterns," The Journal of Agricultural Sciences, Vol. 147, No. 4, 2009, pp. 437-444. doi: $10.1017 / \mathrm{S} 0021859609008612$

[40] A. Guóoth , I. Tari , A. Gallé , J. CSiszár , A. Pecsváradi , Cseuz and L. Erdei, "Comparison of the Drought Stress Responses of Tolerant and Sensitive Wheat Cultivars during Grain Filling : Changes in Flag Leaf Photosynthetic Activity, ABA Levels and Grain Yield," Journal of Plant Growth Regulation, Vol. 28 , No. 2, 2009, pp. 167-176. doi:10.1007/s00344-009-9085-8

[41] I. F. Wardlaw and J. Willenbrink, "Mobilization of Fructan Reserves and Changes in Enzyme Active Ities in Wheat Stems Correlate with Water Stress during Kernel Filling," New Phytologist, Vol. 148, No. 3, 2000, pp. 413-422. doi:10.1046/j.1469-8137.2000.00777.x 